\title{
COVID-19, public health and constructive journalism in Canada
}

\section{La COVID-19, la santé publique et le journalisme constructif au Canada}

\author{
Noni E. MacDonald ${ }^{1}$ \\ Published online: 17 February 2021 \\ (C) The Canadian Public Health Association 2021
}

\section{Public experts and the media}

Because of the COVID-19 pandemic, Canadians have, for almost a year, had the chance to see the full scope of scientific activity taking place in the public health sphere. Many of our colleagues working in public health (whether in research or practice) have received frequent interview requests from both print and digital media outlets. They have given numerous interviews and answered thousands of questions to support journalists, who inform the public. The Journal interviewed two public health researchers who have been highly visible in the English and French media to share their thoughts on this experience. Dr. Noni MacDonald is a pediatrician at the IWK Health Centre, which is affiliated with Dalhousie University in Halifax. She is a vaccination specialist and has collaborated regularly with The Globe and Mail and the CBC over the past year. Dr. Roxane Borgès Da Silva is a health economist at the Université de Montréal's School of Public Health and has been interviewed by journalists from many radio and television stations and Montréal's La Presse and Le Devoir. - Louise Potvin, Editor-in-Chief

\section{La présence médiatique des experts en santé publique}

La pandémie de COVID-19 a été l'occasion depuis près d'un an pour nos concitoyens et concitoyennes de découvrir toute

Noni E. MacDonald

noni.macdonald@dal.ca

1 Department of Pediatrics, IWK Health Centre, Dalhousie University, Halifax, Nova Scotia, Canada l'étendue de l'activité scientifique de la santé publique. Plusieurs parmi nos collègues impliqués dans la recherche ou la pratique en santé publique ont été régulièrement sollicités par la presse écrite ou les média électroniques. Ils et elles ont donné quantité d'entrevues, ont répondu à des milliers de questions pour soutenir le travail des journalistes pour informer la population. La Revue a demandé à deux chercheures de santé publique qui ont été largement visibles, l'une dans les média de langue anglaise et l'autre dans les média de langue française, de livrer leurs réflexions sur cette expérience. $D^{r e}$ Noni MacDonald est pédiatre au IWK Health Centre affilié à l'Université Dalhousie à Halifax. Elle est une spécialiste de la vaccination et elle a collaboré régulièrement avec le Globe and Mail et la CBC au cours de la dernière année. Pour sa part, $P^{r e}$ Roxane Borgès Da Silva est une économiste de la santé à l'École de santé publique de l'Université de Montréal et elle a très souvent été interviewée par les journalistes de La Presse et du Devoir à Montréal, de même que par de très nombreux journalistes de la radio et de la télévision. — Louise Potvin, Rédactrice en chef

The COVID-19 pandemic has touched everyone in Canada; for some, directly impacting their health or that of a loved one, neighbour or colleague. For even more, COVID-19 has disrupted society as we know it; a direct effect on our wellbeing and quality of life. For journalists and reporters, not only has COVID affected how, where and when they work, but COVID-19 stories have dominated formal media stories for much of 2020, whether this was politics, business, sports, health or lifestyle reports. Television, radio and print media had an insatiable appetite for updates and answers to everchanging questions as COVID-19 science evolved and the impact of the pandemic deepened. 
In general, journalists write and assemble stories that will be of interest to their audience. They educate their audiences about public events and issues and how these will affect our lives. Background for stories comes from interviews with those affected and with experts in the field the story is addressing, as well as through reviewing reports of new discoveries, science articles, "reliable" websites on the topic and searches for information on the internet. For COVID-19, the first quarter of 2020 suffered from such an avalanche of information, misinformation and disinformation that the Director-General of the World Health Organization (WHO) noted that "We're not just fighting an epidemic; we're fighting an infodemic" (World Health Organization 2020a).

Journalists and reporters in Canada were not immune. There were often too many experts, with only some actually having specific backgrounds and technical expertise relevant and related to the aspect of COVID being reported upon. Some public health experts came across as too academic, too distant from the public, and/or appeared inconsistent or conflicting in the recommendations put forward. There was often too much speculation, based on too little science, by both public health and (more so) non-public health experts. The debacle/distraction/confusion/alarm over the potential for small particle aerosol transmission of COVID is an example of this.

While airborne transmission (small particle aerosols) can occur during medical aerosol-generating procedures and may play a role in poor ventilation settings, the epidemiology and clinical evidence suggest that the SARS-CoV-2 virus is primarily transmitted between people via respiratory droplets and contact routes (World Health Organization 2020b). This is why the WHO (2020b), Infection Prevention and Control Canada (2020), the United States Centers for Disease Control and Prevention (2020), and the European Centre for Disease Prevention and Control (2020) all recommend masks, social distancing and handwashing control measures for the public, and standard institutional respiratory droplet and contact control measures for health care workers (masks, gowns, gloves, eye protection, handwashing), with added airborne precautions (respirators) when and where aerosol-generating procedures are being performed. Even in the invited commentary on the topic in Clinical Infectious Diseases that raised much public concern about the aerosols due to media attention, not only were the respiratory and contact routes acknowledged, the airborne route was noted only as a potential route (Morawska and Milton 2020). The precautionary principle was emphasized. An engineering review of COVID-19 transmission by droplets and aerosols noted the unresolved dichotomy but did not provide clinical evidence beyond a few reports to show aerosols were of great significance for transmission in public (Jayaweera et al. 2020).

Many in public health recognized early on that the crisis was only going to grow. Public behaviour change was required - always a difficult task. The value of social marketing strategies was clear (Evans 2006). Complex science had to be explained. Who would have speculated in 2019 that many ordinary Canadians would come to understand and even knowledgeably discuss things like the flattening of an epidemic curve and the R naught, to widely utilize needed COVID-19 self-protection measures, and to accept lockdowns, albeit sometimes grudgingly.

Some journalists and reporters did recognize early on the huge public thirst to know about what was happening now, what might happen and what needed to be done. Over the year, many noted that the public wanted hope, not just horror. Many are trying to practice constructive journalism - an approach with roots in positive psychology that aims to restore the balance by looking at solutions, not just reporting the problem (Mast et al. 2019). News items can be alarming, such as the detection in the United Kingdom of a mutant variant of COVID-19 that appears to be more easily transmissible (Mahase 2020). Adding the information that it does not appear to cause more severe disease, it can be detected with current tests, and current personal protective equipment remains an important prevention measure was reassuring to readers and an example of constructive journalism in action.

Given that the COVID-19 pandemic is far from over, how can constructive journalism on COVID-19 be fostered? What can public health do?

This is complex work. Public health professionals play key roles in social marketing for improved health behaviours as well as in managing public expectations. Working with journalists and reporters is one important component. Being accessible, answering queries the public raise, explaining why control programs such as mass vaccination take so much time, explaining the science, and outlining strategies to address the road bumps in controlling COVID-19 are crucial but do not go far enough if constructive journalism is to be fostered. Media contacts are needed at all levels - not just nationally but also regionally and locally. Public health spokespeople need to be well briefed, but in addition, the media, whether national, regional or local, need to be educated to understand nuances; to discern what is new science needing to be highlighted and what is just lightweight attention-grabbing fluff that deserves little attention; to ask what are the solutions to the problems being raised and, if unknown now, when will we know more.

So how did we do overall- public health, journalists and the public - with regard to dealing with COVID-19 in 2020? A solid "B". We did better than many other countries but we had failures: too much hype and too many stories that lacked solid science, too much conflicting advice early on, too many horror stories - some with foundation in fact, others without — but public health has learned to interact more effectively with journalists and the public, and many journalists have toned down sensationalism in favour of fact and evidence. Public health needs to tune up their social marketing 
plans as vaccines are rolled out, and journalists need to receive positive reinforcement for constructive journalism. We are all in this together-not a them versus us scenario. Public health should not be shy to contact a journalist to compliment a story that is well done, but equally to do so when there are errors, to explain the science and why getting a particular point correct is important. When an expert is not really an expert for a specific question - e.g., has depth of knowledge but too narrow a perspective - this needs to be pointed out. We do not need more fine particle aerosol-like distractions when the major evidence is on large respiratory droplet and contact transmission. The path to pandemic control in Canada is still long with many bumps ahead. Having public health foster constructive journalism will help make the bumps smaller and the path forward seem easier.

\section{Éditorial invité}

Tout le monde est concerné par la pandémie de COVID-19 au Canada; pour certains, elle affecte directement leur santé ou celle d'un proche, d'un voisin ou d'un collègue. Pour un nombre encore plus grand, la COVID-19 a perturbé la société telle que nous la connaissons et a eu un effet direct sur le bien-être et la qualité de vie. Pour les journalistes et les reporters, non seulement la COVID a-t-elle changé la façon, l'endroit et le moment où ils travaillent, mais elle a dominé les reportages officiels pendant la plus grande partie de 2020, que ce soit la politique, les affaires, le sport, la santé ou les modes de vie. La télévision, la radio et la presse écrite ont un appétit insatiable pour les dernières nouvelles et les réponses à des questions qui ne cessent de changer à mesure que la science de la COVID-19 évolue et que les répercussions de la pandémie s'aggravent.

En général, les journalistes rédigent et regroupent des articles qui intéresseront leur auditoire. Ils et elles sensibilisent cet auditoire aux événements et aux enjeux publics et à leurs conséquences futures dans nos vies. Le contexte des articles vient d'entrevues avec les personnes touchées et les spécialistes du domaine en question, et de l'examen de reportages de nouvelles découvertes, d'articles scientifiques, de sites « fiables » sur le sujet et de recherches sur Internet. Pour la COVID-19, il y a eu une telle avalanche d'informations, de mésinformation et de désinformation au premier trimestre de 2020 que le directeur général de l'Organisation mondiale de la santé (OMS) a fait remarquer : «Nous ne combattons pas seulement une épidémie; nous luttons aussi contre une infodémie » (World Health Organization 2020a).

Les journalistes et les reporters du Canada n'ont pas été à l'abri. Ils ont souvent interrogé trop de spécialistes, dont quelques-uns seulement possédaient vraiment le bagage scientifique et les compétences techniques pertinents et liés à l'aspect de la COVID faisant l'objet du reportage. Certains spécialistes de la santé publique ont donné l'impression d'être des intellectuels enfermés dans leur tour d'ivoire, et leurs recommandations ont semblé contradictoires ou manquer de cohérence. Tant les spécialistes de la santé publique et (encore plus) de l'extérieur du domaine ont souvent émis trop d'hypothèses fondées sur des bases scientifiques précaires. La débâcle/la distraction/la confusion/l'alarme au sujet de la transmission potentielle de la COVID par les aérosols à fines particules en est un exemple.

Il peut y avoir dissémination aérienne (par les aérosols à fines particules) durant les interventions médicales produisant des aérosols, et cette dissémination peut jouer un rôle dans les lieux mal ventilés, mais selon les preuves épidémiologiques et cliniques, le virus SRAS-Cov-2 est principalement transmis d'une personne à l'autre par les gouttelettes de salive et les contacts (World Health Organization 2020b). C'est pourquoi l'OMS (2020b), l'organisme Prévention et contrôle des infections Canada (2020), les Centers for Disease Control and Prevention américains (2020) et le Centre européen pour la prévention et le contrôle des maladies (2020) recommandent tous au public les masques, la distanciation sociale et le lavage des mains comme mesures de contrôle, et aux agents de santé, les mesures institutionnelles standard pour limiter les gouttelettes de salive et les contacts (masques, blouses, gants, protecteurs oculaires, lavage des mains), en ajoutant des précautions contre les infections aéroportées (appareils de protection respiratoire) aux moments et aux endroits où des interventions produisant des aérosols sont effectuées. Même dans le commentaire invité sur le sujet dans la revue Clinical Infectious Diseases, qui a suscité beaucoup d'inquiétude au sujet des aérosols dans l'opinion publique quand les médias en ont eu vent, non seulement la transmission par les gouttelettes de salive et les contacts est-elle reconnue, mais la transmission aéroportée n'est citée que comme une voie potentielle (Morawska and Milton 2020). Le principe de précaution est souligné. Un examen technique de la transmission de la COVID-19 par les gouttelettes et les aérosols a fait mention de la dichotomie non résolue, mais à part quelques rapports, il n'a pas fourni de preuves cliniques que les aérosols jouent un rôle significatif dans la transmission en public (Jayaweera et al. 2020).

Beaucoup de gens de la santé publique ont vite reconnu que la crise ne ferait que prendre de l'ampleur. Il fallait changer les comportements du public_-toujours une tâche difficile. La valeur des stratégies de marketing social était claire (Evans 2006). Il fallait expliquer la science dans toute sa complexité. Qui aurait cru en 2019 que de nombreux citoyens ordinaires en viendraient à comprendre des sujets comme l'aplanissement d'une courbe épidémique et le Rzéro et même à en discuter en connaissance de cause, à utiliser à grande échelle les mesures d'autoprotection nécessaires contre la COVID-19 et à accepter les confinements, bien que parfois à contrecœur? 
Certains journalistes et reporters ont vite reconnu l'énorme soif du public de savoir ce qui était en train de se produire, ce qui pourrait se produire et ce qu'il fallait faire. Au cours de l'année, beaucoup ont indiqué que le public voulait de l'espoir, pas seulement de l'horreur. Beaucoup essaient de faire du journalisme constructif, une démarche qui vient de la psychologie positive et qui vise à retrouver l'équilibre en envisageant des solutions, et non pas seulement en communiquant des informations sur le problème (Mast et al. 2019). Les nouvelles sont parfois alarmantes, comme la détection au Royaume-Uni d'un variant mutant de la COVID-19 qui semble être plus facilement transmissible (Mahase 2020). Il était rassurant pour les lecteurs, en plus d'être un exemple de journalisme constructif à l'œuvre, d'ajouter que le variant ne semble pas causer une forme plus grave de la maladie, que les tests actuels peuvent le détecter, et que l'équipement de protection individuelle actuel demeure une importante mesure de prévention.

Comme la pandémie de COVID-19 est loin d'être terminée, comment peut-on favoriser des reportages constructifs sur la COVID-19? Que peut faire la santé publique?

La tâche est complexe. Les professionnels de la santé publique jouent des rôles clés dans le marketing social de comportements de santé améliorés et dans la gestion des attentes du public. La collaboration avec les journalistes et les reporters est un élément important. Il est essentiel d'être accessible, de répondre aux questions soulevées par le public, d'expliquer pourquoi les programmes de contrôle comme la vaccination de masse prennent autant de temps, d'expliquer les fondements scientifiques et de décrire des stratégies pour contourner les embûches dans la lutte contre la COVID-19, mais cela ne va pas assez loin pour favoriser le journalisme constructif. Des contacts avec les médias sont nécessaires à tous les niveaux, pas seulement à l'échelle nationale, mais aussi régionale et locale. Les porte-parole de la santé publique doivent être bien informés, mais ils doivent en plus apprendre aux médias (nationaux, régionaux ou locaux) à saisir les nuances; à faire la distinction entre un progrès scientifique à souligner et un article qui jette de la poudre aux yeux et ne mérite aucune attention; à demander quelles sont les solutions aux problèmes soulevés et, si elles sont encore inconnues, quand nous en saurons davantage.

Quelle note avons-nous obtenu globalement-la santé publique, les journalistes et le public — dans le dossier de la COVID-19 en 2020? Je nous donnerais un B. Nous avons fait mieux que beaucoup d'autres pays, mais nous avons aussi eu des échecs : trop d'exagération et trop d'articles sans fondements scientifiques, trop de conseils contradictoires au début, trop d'histoires d'horreur-certaines fondées sur les faits, d'autres non-mais la santé publique a appris à interagir plus efficacement avec les journalistes et le public, et de nombreux journalistes ont tempéré le sensationnalisme par les faits et les données probantes. La santé publique a besoin de peaufiner ses plans de marketing social pour le déploiement des vaccins, et les journalistes ont besoin de recevoir du renforcement positif lorsqu'ils font du journalisme constructif. Nous sommes tous dans le même bateau-ce n'est pas « eux contre nous ». Les gens de la santé publique ne devraient pas hésiter à contacter une journaliste pour la féliciter d'un article bien tourné, mais aussi à le faire quand il y a des erreurs, pour expliquer les fondements scientifiques et pourquoi il est important que tel ou tel aspect soit correct. Quand un spécialiste n'est pas vraiment spécialiste d'une question particulière - par exemple s'il a des connaissances approfondies, mais une perspective trop étroite-il faut le lui mentionner. Nous n'avons pas besoin d'autres sources de distraction comme les aérosols à fines particules quand les principaux éléments de preuve indiquent que la transmission se fait par les grosses gouttelettes de salive et les contacts. Le chemin du contrôle de la pandémie au Canada est encore long et semé d'embûches. En favorisant le journalisme constructif, les gens de la santé publique aideront à contourner ces embûches et à faire en sorte que la voie à suivre semble plus facile.

\section{References/Références bibliographiques}

European Centre for Disease Prevention and Control. (2020). https:// www.ecdc.europa.eu/sites/default/files/documents/Infectionprevention-and-control-in-healthcare-settings-COVID-19_4th update.pdf. Accessed 8 Jan 2021.

Evans, W. D. (2006). How social marketing works in health care. $B M J$, 332(7551), 1207-1210.

Infection Prevention and Control Canada. (2020). https://ipac-canada. org/guidance-documents-national-and-international.php. Accessed 8 Jan 2021.

Jayaweera, M., Perera, H., Gunawardana, B., \& Manatunge, J. (2020). Transmission of COVID-19 virus by droplets and aerosols: A critical review. Environmental Research, 188, 109819. https://oi.org/ 10.1016/j.envres.2020.109819.

Mahase, E. (2020). Covid-19: What have we learnt about the new variant in the UK? BMJ, 371, m4944. https://doi.org/10.1136/bmj.m4944.

Mast, J., Coesemans, R., \& Temmerman, M. (2019). Constructive journalism: concepts, practices, and discourses. Journalism, 20(4), 492-503.

Morawska, L., \& Milton, D. K. (2020). It is time to address airborne transmission of coronavirus disease 2019 (COVID-19). Clinical Infectious Diseases, 71, 2311-2313.

United States Centers for Disease Control and Prevention. (2020). https:// www.cdc.gov/coronavirus/2019-ncov/hcp/infection-controlrecommendations.html. Accessed 8 Jan 2021.

World Health Organization. (2020a). https://www.un.org/en/uncoronavirus-communications-team/un-tackling-\%E2\%80\% 98infodemic\%E2\%80\%99-misinformation-and-cybercrime-covid19. Accessed 8 Jan 2021.

World Health Organization. (2020b). Transmission of SARS-CoV-2: Implications for infection prevention precautions. July 9, 2020. Geneva: World Health Organization https://www.who.int/newsroom/commentaries/detail/transmission-of-sars-cov-2-implicationsfor-infection-prevention-precautions. Accessed 8 Jan 2021.

Publisher's note Springer Nature remains neutral with regard to jurisdictional claims in published maps and institutional affiliations. 